\title{
PENERAPAN METODE VECTOR AUTO REGRESSION DALAM INTERAKSI KEBIJAKAN FISKAL DAN MONETER DI INDONESIA
}

\author{
Adrian Sutawijaya dan Etty Puji Lestari \\ Fakultas Ekonomi Universitas Terbuka \\ Jalan Cabe Raya, Pondok Cabe, Pamulang, Tangerang Selatan 15418 Banten Telp: +6221 7490941 \\ E-mail: adrian@ut.ac.id
}

Diterima 30 Juni 2012 / Disetujui 4 Maret 2013

\begin{abstract}
The purpose of this study is to analyze the interaction of fiscal and monetary policy in Indonesia, especially after the introduction of fiscal and monetary policy shocks. The research method used is the vector autoregression (VAR). VAR is usually used for projecting coherent system variables and time to analyze the dynamic impact of disturbance factors contained in the system variables. Variables used in this study is the level of interest rates as a proxy for monetary policy instruments, government expenditures as a proxy for fiscal policy, inflation rates and national income. The results show that fiscal policy is a negative shock to inflation and responded with a tight monetary policy, while the shock in monetary policy will reduce national income. The application of fiscal and monetary policies that will effectively promote economic growth.
\end{abstract}

Keywords: fiscal policy, monetary policy, vector autoregression, dynamic impact

\begin{abstract}
Abstrak: Tujuan dari penelitian ini menganalisis interaksi kebijakan fiskal dan moneter di Indonesia, terutama setelah guncangan kebijakan moneter dan fiskal. Metode penelitian yang digunakan adalah vector autoregresi (var). VAR biasa digunakan untuk memproyeksikan variabel sistem koheren dan waktu menganalisis dampak dinamis faktor gangguan yang terdapat dalam variabel sistem. Variabel yang digunakan dalam penelitian ini adalah tingkat suku bunga sebagai proxy untuk instrumen kebijakan moneter, pengeluaran pemerintah sebagai proxy untuk kebijakan fiskal, inflasi dan pendapatan nasional. Hasil penelitian menunjukkan bahwa kebijakan fiskal merupakan guncangan negatif terhadap inflasi dan direspon dengan kebijakan moneter ketat, sedangkan guncangan kebijakan moneter akan mengurangi pendapatan nasional. Penerapam kebijakan moneter dan fiskal akan menaikkan pertumbuhan ekonomi secara efektif.
\end{abstract}

Kata kunci: kebijakan fiskal, kebijakan moneter, vektor autoregresi, dampak dinamis

\section{PENDAHULUAN}

Kebijakan fiskal dan kebijakan moneter sangat diperlukan untuk mencapai target-target ekonomi yang telah ditetapkan. Perpaduan antara kebijakan fiskal dan kebijakan moneter sangat diperlukan untuk menetapkan dan mencapai target-target moneter dan defisit fiskal secara konsisten untuk mencapai pembangunan ekonomi yang cukup tinggi dan stabil (Claeys, 2005). Namun demikian, interaksi kebijakan fiskal dan moneter juga menjadi perdebatan dikalangan ekonom dan pengambil kebijakan. Pada satu sisi, kebijakan moneter diarahkan pada pencapaian target menjaga stabilitas tingkat harga, sementara di sisi lain kebijakan fiskal ditetapkan untuk mencapai pertumbuhan ekonomi. Permasalahan utama interaksi kebijakan fiskal dan moneter terletak pada terjadinya trade-off antara pencapaian stabilitas harga dan pertumbuhan ekonomi terutama dalam jangka pendek (Champbell dan Lewis, 2000). 
Dampak defisit fiskal yang tinggi dapat menyebabkan kenaikan tingkat inflasi, begitu halnya perekonomian dengan tingkat inflasi yang tinggi juga memberikan dampak negatif bagi pertumbuhan ekonomi (Bank Indonesia, 2003).

Kinerja perekonomian Indonesia menunjukkan bahwa defisit anggaran mampu dikendalikan pada level 1,0\% dari PDB pada tahun 2006 walaupun lebih tinggi dari sasaran awal 0,7 persen dari PDB (Bank Indonesia, 2007). Terkendalinya defisit anggaran ini mampu memberikan stimulus pertumbuhan ekonomi mencapai 5,5 persen pada tahun 2006. Sementara itu dari sisi moneter, stabilitas harga tetap terjaga dengan pengendalian inflasi pada level 6,60 persen (y-oy) dibandingkan awal tahun 2006 yang mencapai 17,03 persen (y-oy) (Bank Indonesia, 2007). Hal ini juga ditandai dengan menurunnya tingkat suku bunga SBI sehingga kondisi tersebut memberikan sinyal yang positif bagi sektor riil.

Perkembangan perekonomian yang semakin dinamis dan terintegrasi dengan perekonomian dunia memberikan implikasi penting bagi para pelaku ekonomi terutama dalam pengambilan kebijakan makroekonomi. Kebijakan fiskal dan kebijakan moneter merupakan bagian integral dari kebijakan makroekonomi yang memiliki target yang harus dicapai baik dalam jangka pendek dan jangka panjang (Indrawati, 2007). Pengelolaan kebijakan fiskal dan moneter melalui koordinasi yang baik akan memberikan sinyal positif bagi pasar dan menjaga stabilitas makroekonomi. Keselarasan kebijakan fiskal dan moneter di Indonesia pada tahun terakhir menunjukkan perkembangan yang baik. Dari sisi kebijakan fiskal, dengan tetap menjaga kesinambungan fiskal, pemerintah mampu memberikan stimulus untuk mendorong pertumbuhan ekonomi.

Interaksi kebijakan fiskal dan moneter menjadi perdebatan dikalangan ekonom dan pengambil kebijakan. Pada satu sisi, kebijakan moneter diarahkan pada pencapaian target menjaga stabilitas tingkat harga, sementara di sisi lain kebijakan fiskal ditetapkan untuk mencapai pertumbuhan ekonomi. Titik utama permasalahan dalam interaksi kebijakan fiskal dan moneter terletak pada terjadinya trade-off antara pencapaian stabilitas harga dan pertumbuhan ekonomi terutama dalam jangka pendek. Defisit fiskal yang tinggi dapat menyebabkan kenaikan tingkat inflasi, dan sebaliknya perekonomian dengan tingkat inflasi yang tinggi juga memberikan dampak negatif bagi pertumbuhan ekonomi. Berdasarkan latar belakang tersebut maka timbulah pertanyaan penelitian: Bagaimana interaksi kebijakan fiskal dan moneter di Indonesia yang dipengaruhi oleh adanya shock perekonomian dalam kurun waktu 1980-2008, dan bagaimana peran variabel-variabel makroekonomi dalam penerapan kebijakan fiskal dan moneter dalam mempengaruhi pertumbuhan ekonomi di Indonesia. Tujuan Penelitian ini adalah Menganalisis interaksi kebijakan fiskal dan moneter di Indonesia dengan melihat respon pertumbuhan ekonomi terhadap shock yang terjadi di Indonesia dalam kurun waktu 1980-2008 dan menganalisis peran variabel-variabel makroekonomi dalam penerapan kebijakan fiskal dan moneter yang mempengaruhi pertumbuhan ekonomi di Indonesia.

Kebijakan Fiskal dalam Perspektif Teori. Penerimaan dan pengeluaran pemerintah diyakini dapat memberikan pengaruh terhadap kestabilan perekonomian suatu negara. Pengeluaran pemerintah yang terlalu besar dapat menyebabkan terjadinya defisit dalam APBN sehingga akan mempengaruhi variabel lainnya. Untuk menjaga kestabilan ekonomi maka penerimaan dan pengeluaran pemerintah perlu diseimbangkan. Maka timbulah gagasan untuk sengaja mengubah-ubah pengeluaran dan penerimaan pemerintah guna mencapai kestabilan ekonomi. Teknik mengubah pengeluaran dan penerimaan pemerintah inilah yang kita kenal dengan kebijakan fiskal (Santosa dan Lestari, 2008).

Pada awal sebelum terjadinya depresi ekonomi tahun 1930, pengeluaran pemerintah hanya dianggap sebagai alat untuk membiayai kegiatan-kegiatan pemerintah dan dinilai berdasarkan manfaat langsung yang dapat ditimbulkannya tanpa melihat pengaruhnya terhadap pendapatan nasional. Demikian pula halnya dengan pajak. Pajak hanya dianggap sebagai sumber pembiayaan pengeluaran negara dan belum diketahui pengaruhnya terhadap pendapatan nasional. Akibatnya dalam masa 
depresi, di mana penerimaan pemerintah menurun, maka pengeluaran pemerintah harus dikurangi pula. Hal ini justru berakibat pada semakin rendahnya pendapatan nasional serta semakin lesunya perekonomian. Kalau timbul deflasi atau inflasi, kebijakan yang dipercayai untuk menanggulanginya adalah kebijakan moneter lewat Bank Sentral dan bukan kebijakan fiskal (Suparmoko, 2000).

Kebijakan fiskal merupakan proses pembentukan perpajakan dan pengeluaran pemerintah dalam upaya menekan fluktuasi siklus ekonomi dan berperan dalam menjaga ekonomi yang tumbuh dengan penggunaan tenaga kerja yang tinggi sehingga tidak terjadi laju inflasi yang tinggi dan berubah-ubah (Samuelson, 1985). Tindakan fiskal biasanya dilakukan dalam situasi dimana laju inflasi sangat tinggi akibat output yang melonjak tajam. Pada kondisi ini pemerintah dapat mengambil keputusan menaikkan tarif pajak dan atau menurunkan pengeluaran publik. Dari sisi moneter, bank sentral bisa saja mengurangi jumlah uang beredar dan sekaligus menaikkan suku bunga, dengan tujuan menekan laju inflasi.Kebijakan tersebut dikenal dengan kebijakan moneter.

Kebijakan fiskal merupakan kebijakan ekonomi yang digunakan oleh pemerintah untuk mengelola atau mengarahkan perekonomian ke kondisi yang lebih baik atau yang diinginkan dengan mengubah-ubah penerimaan pajak dan pengeluaran negara. Kebijakan fiskal dapat digunakan untuk menstabilkan permintaan agregat, tingkat produksi, dan kesempatan kerja. Ketika permintaan agregat tidak cukup untuk memastikan penyerapan tenaga kerja penuh, maka pemerintah dalam ruang lingkup fiskal harus meningkatkan anggaran belanja negara dan memotong pajak. Sebaliknya ketika permintaan agregat berlebihan sehingga berisiko meningkatkan inflasi, maka pemerintah harus memotong anggaran belanja negara dan meningkatkan penerimaan pajak.

Tujuan kebijakan fiskal cenderung berbeda antara negara maju dan negara berkembang. Di negara-negara maju, peranan kebijakan fiskal umumnya untuk mempertahankan full employment dan menstabilisasi pertumbuhan ekonomi. Sebaliknya di negara-negara berkembang, kebijakan fiskal digunakan untuk menciptakan sua- tu lingkungan yang baik bagi pertumbuhan ekonomi yang cepat.

Pengaruh Kebijakan Fiskal dari Sisi Permintaan. Pengaruh kebijakan fiskal dari sisi permintaan ini lebih lanjut diklasifikasikan berdasarkan perspektif mainstream utama dalam teori ekonomi, yaitu Keynesian dan Non-Keynesian.

a. Pendekatan Keynesian. Model Keynesian yang paling sederhana mengasumsikan adanya kekakuan harga (price rigidity) dan perekonomian mengalami kelebihan kapasitas (excess capacity), sehingga output ditentukan oleh permintaan agregat (aggregate demand). Dalam model ini, ekspansi fiskal mempunyai efek pengganda (multiplier effect) terhadap permintaan agregat dan output. Ekspansi fiskal mendorong peningkatan permintaan agregat melalui salah satu dari dua saluran, yaitu: Pertama, apabila pemerintah meningkatkan belanja dan penerimaan pajak diasumsikan tetap sama, maka permintaan agregat akan bertambah secara langsung. Kedua, apabila pemerintah mengurangi pajak (tax cuts) atau menaikkan transfer payments, maka pendapatan masyarakat yang dapat dibelanjakan (disposable income) akan bertambah, dan masyarakat cenderung menambah konsumsi. Peningkatan konsumsi yang peka (responsiveness) terhadap perubahan pendapatan ini mempengaruhi pengganda Keynesian dengan nilai lebih besar dari satu, dan dengan kecenderungan meningkat. Nilai pengganda Keynesian lebih besar untuk peningkatan belanja dibandingkan untuk pemotongan pajak.

Apabila peningkatan belanja diimbangi dengan peningkatan pajak, maka hasilnya adalah nilai pengganda anggaran berimbang (balanced budget multiplier) persis sama dengan satu. Sementara itu, dalam model Keynesian yang diperluas (model IS-LM standar) dikemukakan bahwa kebijakan fiskal juga dapat mengubah komposisi permintaan agregat. Apabila pemerintah menjalankan defisit anggaran, sejumlah pembiayaan akan dipenuhi dengan menerbitkan obligasi, sehingga pemerintah berkompetisi dengan sektor swasta untuk mendapatkan dana masyarakat. Hal ini akan mendorong naiknya suku bunga dan memungkinkan terjadinya "crowding out" investasi swasta. 
Dengan demikian, ekspansi fiskal yang dikompensasi dengan tambahan pinjaman menyebabkan suku bunga naik lebih tinggi dan selanjutnya mengurangi investasi. Crowding out mungkin menjadi lebih besar apabila investasi sensitif terhadap suku bunga. Namun demikian, apabila investasi merupakan fungsi dari pendapatan sekarang (current income) sesuai konsep dalam model akselerator pengganda (multiplieraccelerator models) bisa menghasilkan pengganda fiskal yang cukup besar. Kemungkinan crowding out juga bisa terjadi melalui nilai tukar, terutama untuk perekonomian terbuka, sebagaimana dikemukakan dalam model IS-LM (Mundell-Fleming).

Suku bunga yang lebih tinggi merangsang masuknya modal dari luar negeri (capital inflows) yang pada gilirannya menyebabkan nilai tukar mengalami apresiasi (penguatan). Apresiasi ini menyebabkan barang-barang yang diimpor menjadi lebih murah dan ekspor menjadi lebih mahal. Implikasinya, karena terjadinya peningkatan permintaan domestik yang berasal dari ekspansi fiskal, maka kondisi neraca transaksi berjalan (current accounts) menjadi lebih buruk. Derajat crowding out juga dipengaruhi oleh fleksibilitas harga. Model Neo Keynesian menganggap bahwa harga yang fleksibel, walaupun dibatasi dalam jangka pendek, cenderung mempersempit rentang nilai yang ditimbulkan oleh pengganda fiskal, dan membatasi pengaruh rezim nilai tukar. Dalam perekonomian tertutup, ekspansi fiskal akan menyebabkan harga-harga lebih tinggi dan menghambat kenaikan permintaan agregat dalam jangka pendek, dengan mendorong crowding out melalui suku bunga yang terjadi dengan rijiditas harga. Dalam perekonomian terbuka dengan nilai tukar fleksibel, derajat crowding tergantung pada respon harga-harga domestik terhadap perubahan nilai tukar. Perubahan suku bunga, nilai tukar, dan hargaharga bisa mempengaruhi crowding out melalui efek kekayaan (wealth effects) terhadap permintaan agregat (Nizar, 2010).

b. Pendekatan Non-Keynesian. Pendekatan ini berasal dari model Neo-klasik yang menyoroti kelemahan-kelemahan pendekatan Keynesian. Meskipun model Neo-klasik memberikan penekanan pada efek kebijakan fiskal dari sisi penawaran (supply-side effects), namun ada beberapa karakteristik model ini yang memiliki implikasi terhadap permintaan. Menurut model Neo-klasik, apabila konsumen berorientasi ke masa depan dan sangat sadar tentang konstrain anggaran antarwaktu pemerintah (government's intertemporal budget constraint), maka konsumen beranggapan bahwa pemotongan pajak sekarang akan dibiayai melalui utang oleh pemerintah. Akibatnya di masa yang akan datang pajak yang dikenakan lebih tinggi. Argumen ini dikenal dengan Ricardian equivalence. Dengan demikian, antara pajak dan utang memiliki Ricardian equivalence. Ricardian equivalence yang sempurna menunjukkan bahwa penurunan tabungan pemerintah akibat pemotongan pajak akan diimbangi dengan tabungan swasta yang lebih tinggi, dan permintaan agregat tidak terpengaruh. Pengganda fiskal dalam kasus ini adalah nol.

Fokus dalam Ricardian equivalence adalah pada efek pemotongan pajak lump-sum untuk arah belanja pemerintah tertentu. Dengan pajak proporsional atau progresif, pemotongan pajak akan mempengaruhi pendapatan permanen. Apabila ekspansi fiskal (peningkatan belanja pemerintah), maka dampaknya terhadap pendapatan permanen tergantung pada bagaimana ekspansi fiskal dibiayai dimasa yang akan datang. Peningkatan belanja pemerintah yang bersifat temporer tidak akan berpengaruh karena diimbangi dengan pemotongan belanja dimasa mendatang. Namun demikian, peningkatan belanja pemerintah yang dibiayai melalui pajak yang lebih tinggi dimasa mendatang akan menyebabkan penurunan pendapatan permanen dan konsumsi

Pengaruh Kebijakan Fiskal dari Sisi Penawaran. Selain pengaruhnya terhadap permintaan agregat dan tabungan, kebijakan fiskal juga mempengaruhi perekonomian melalui perubahan insentif. Pengenaan tarif pajak marjinal yang tinggi atas pendapatan berpotensi mengurangi insentif untuk menghasilkan pendapatan. Para ekonom "supply-side" menyatakan bahwa pengurangan tarif pajak akan berpengaruh besar terhadap jumlah tenaga kerja yang ditawarkan, dan juga terhadap output. Pengaruh insentif terhadap pajak juga memainkan peranan pada sisi permintaan. Kebijakan kredit pajak 
investasi, misalnya, dapat mempengaruhi permintaan atas barang-barang modal.

Kebijakan yang hanya mempromosikan respon sisi penawaran bisa mengatasi konstrain kapasitas, dan dampaknya terutama dalam jangka panjang. Namun demikian, efek sisi penawaran dari kebijakan fiskal bisa memiliki konsekuensi pada sisi permintaan dalam jangka pendek karena ekspektasi pertumbuhan jangka panjang yang lebih tinggi. Apabila ekspansi fiskal dilakukan melalui pemotongan pajak dan peningkatan belanja untuk sisi penawaran, hal ini akan cenderung meningkatkan pengganda fiskal. Untuk menilai dampak kebijakan fiskal jangka pendek dari sisi penawaran yang harus diperhatikan adalah pengaruh perubahan pendapatan tenaga kerja terhadap penawaran tenaga kerja dan pengaruh perubahan pajak modal (capital taxes) terhadap tabungan dan investasi. Selain itu, pengaruh perubahan belanja terhadap produktivitas tenaga kerja dan modal juga harus mendapatkan perhatian, khususnya belanja pemerintah untuk barang-barang publik dan barang-barang lainnya dengan eksternalitas positif (Nizar, 2010).

Interaksi Kebijakan Fiskal dan Moneter. Keberadaan kebijakan fiskal dan kebijakan moneter tidak dapat dipisahkan untuk mencapai target-target ekonomi yang telah ditetapkan. Perpaduan antara kebijakan fiskal dan kebijakan moneter sangat diperlukan untuk menetapkan dan mencapai target-target moneter dan defisit fiskal secara konsisten dalam rangka mencapai pembangunan ekonomi yang cukup tinggi dan stabil. Kebijakan fiskal akan mempengaruhi perekonomian melalui penerimaan negara dan pengeluaran negara. Selain pengaruh dari selisih antara penerimaan dan pengeluaran (defisit atau surplus), perekonomian juga dipengaruhi oleh jenis sumber penerimaan Negara dan bentuk kegiatan yang dibiayai pengeluaran negara.

Dari perhitungan penerimaan dan pengeluaran negara tersebut akan diperoleh besarnya surplus atau defisit APBN. Jika terdapat surplus dalam APBN akan menimbulkan efek kontraksi dalam perekonomian yang besarnya tergantung pada besarnya surplus tersebut. Pada umumnya surplus tersebut dapat digunakan sebagai cadangan atau membayar utang pemerintah (prepayment). Apabila terjadi defisit maka defisit tersebut dapat dibiayai dengan pinjaman luar negeri (official foreign borrowing) atau dengan pinjaman dalam negeri. Pinjaman dalam negeri dapat diperoleh dalam bentuk pinjaman perbankan dan non perbankan yang mencakup penerbitan obligasi negara (government bonds) dan privatisasi (Usman, 2004).

Defisit APBN berpotensi menimbulkan efek ekspansi dalam perekonomian. Jika defisit APBN dibiayai dengan pinjaman luar negeri maka hal ini tidak akan menimbulkan tekanan inflasi jika pinjaman tersebut digunakan untuk membeli barang-barang impor, namun jika pinjaman luar negeri tersebut dipergunakan untuk membeli barangdan jasa didalam negeri maka pembiayaan defisit dengan memakai pinjaman luar negeri akan menimbulkan tekanan inflasi. Di sisi lain, pembiayaan defisit APBN dengan penerbitan obligasi negara akan menambah jumlah uang beredar dan menimbulkan tekanan inflasi.

Sementara itu kebijakan moneter pada dasarnya digunakan untuk mencapai enam tujuan pokok yaitu menciptakan kesempatan kerja (high employment); menciptakan pertumbuhan ekonomi (economic growth); stabilisasi harga (price stability); stabilisasi tingkat bunga (interest rate stability); stabilisasi di pasar keuangan (stability of financial market) dan stabilisasi di pasar uang (stability in foreign exchange markets) (Mishkin, 1995). Kebijakan moneter juga dipakai untuk menjaga agar likuiditas dalam perekonomian berada dalam jumlah yang "tepat" sehingga dapat melancarkan transaksi perdagangan tanpa menimbulkan tekanan inflasi (Djojosubroto, 2004). Umumnya pelaksanaan pengaturan jumlah likuiditas dalam perekonomian ini dilakukan oleh Bank Sentral melalui berbagai instrumen

\section{METODE PENELITIAN}

\section{Data dan Variabel}

Penelitian ini menggunakan data sekunder time series tahunan dengan periode pengamatan tahun 1970-2008. Variabel yang digunakan adalah tingkat suku bunga sebagai proxy instrumen kebijakan moneter, pengeluaran pemerintah 
sebagai proxy kebijakan fiskal, tingkat inflasi dan pendapatan nasional. Data-data tersebut diperoleh dari International Financial Statistic dari International Monetary Fund, Statistik Ekonomi dan Keuangan Indonesia dari Bank Indonesia, Badan Pusat Statistik dan sumbersumber relevan lainnya.

\section{Metode Analisis}

(1) Pengujian Kointegrasi. Model penelitian ini merupakan suatu model yang menganalisis data deret waktu (time series). Data deret waktu umumnya bersifat non-stasioner dan diperoleh melalui proses random-walk. Persamaan regresi yang menggunakan peubah-peubah yang nonstasioner akan mengarah kepada hasil yang palsu (spurious) (Gujarati, 2005). Dalam mengembangkan model deret waktu maka perlu dibuktikan, apakah stokastik yang menghasilkan data tersebut dapat diasumsikan tidak bervariasi karena waktu. Jika proses stokastik tetap dari waktu ke waktu, yang berarti prosesnya stasioner, maka dapat disusun suatu model dengan persamaan yang menghasilkan koefisien tetap yang dapat diduga dari data waktu yang lalu.

Kombinasi dari dua seri yang tidak stasioner, akan bergerak ke arah yang sama menuju ekuilibrium jangka panjangnya dan diferensiasi diantara kedua seri tersebut akan konstan. Jika demikian halnya, seri ini dikatakan saling berkointegrasi. Tes kointegrasi pada penelitian ini didasarkan pada pendekatan vector autoregressions (VAR) Johansen. Jika vektor $X t$ adalah vektor variabel endogen dalam VAR dengan panjang lag $p$, maka:

$$
X_{t}=A_{1} X_{t-1}+A_{2} X_{t-2}+\ldots .+A_{p} X_{t-p}+\beta Y_{t}+\varepsilon_{t}
$$

dimana, $X t$ adalah vektor variabel endogen, $A p$ adalah parameter matriks, $\beta$ Yt adalah vektor dari deterministic variable, dan $\varepsilon$ adalah vektor innovations.

Spesifikasi VAR ini dapat dinyatakan dalam bentuk first difference sebagai berikut :

$$
\Delta X_{t}=\Pi X_{t-1}+\sum_{i=j}^{p-1} \Gamma_{i} \Delta X_{t-1}+\beta Y_{t}+\varepsilon_{t}
$$

dimana $\Pi=\sum_{i=1}^{p} A_{1}-I, \quad \Gamma_{i}=-\sum_{j=i+1}^{p} A_{j}$, dan I adalah matriks identitas

Jika tidak terdapat hubungan kointegrasi, model unrestricted VAR dapat diaplikasikan. Tetapi, bila terdapat hubungan kointegrasi antar seri, model Vector Error Correction (VECM) yang dipergunakan. Jumlah vektor kointegrasi diperoleh dengan melihat signifikansi dari $\Pi$, melalui dua likelihood test.

maximum eigenvalue $=\lambda \max =-T \ln \left(1-\hat{\lambda}_{r+1}\right)$

dimana $\hat{\lambda}$ adalah nilai estimasi eigenvalue yang diperoleh dari estimasi terhadap matriks $\Pi$ dan $\mathrm{T}=$ jumlah observasi

Uji berikutnya adalah trace test (uji teras) yaitu mengukur jumlah vektor kointegrasi dalam data, dengan menggunakan pengujian pangkat matriks kointegrasi, dinyatakan sebagai berikut:

trace statistic $=\lambda_{\text {trace }}=-T \sum_{i-r+1}^{n} \ln \left(1-\hat{\lambda}_{i}\right)$

dimana: T adalah jumlah waktu pengamatan, $\hat{\lambda}_{i}$ adalah estimasi eigenvalue yang dihasilkan dari estimasi matriks $\Pi, \mathrm{r}$ adalah pangkat yang mengindikasikan jumlah vektor kointegrasi.

Untuk mengetahui jumlah vektor kointegrasi maka ada tiga kasus yang perlu dipertimbangkan yaitu: (1). Jika tingkatan $\Pi=0$, maka tidak ada informasi jangka panjang dan model VAR dalam beda tingkat pertama (first difference) cocok representasi; (2). Jika tingkatan $\Pi$ penuh, maka $p_{t}$ adalah stasioner dalam levelnya dan VAR dalam first different cocok representasi; dan (3) Jika tingkatan $\Pi$ adalah $0<\mathrm{r}<\mathrm{p}$, maka $\beta p_{t}$ stasioner sekalipun $p_{t}$ tidak stasioner dan bentuk error correction adalah cukup representasi. Dengan mengetahui jumlah vektor kointegrasi r, maka akan diketahui jumlah hubungan kointegrasi antar variabel.

(2) Vector Auto Regresion. Metode Vector Autoregression (VAR) pertama kali dikembangkan oleh Christoper Sims (1980). Kerangka analisis yang praktis dalam model ini akan memberikan informasi yang sistematis dan mampu menaksir dengan baik informasi dalam persamaan yang dibentuk dari data time series. 
Selain itu perangkat estimasi dalam model VAR mudah digunakan dan diintepretasikan. Perangkat estimasi yang akan digunakan dalam model VAR ini adalah fungsi impulse respon dan variance decompotition.

(3) Uji akar unit (Unit Root Test). Uji akar unit ini digunakan untuk melihat apakah data yang diamati stasioner atau tidak. Test ini sebenarnya hanya merupakan pelengkap dari analisis VAR, mengingat tujuan dari analisis VAR adalah untuk menilai adanya hubungan timbal balik di antara variabel-variabel yang diamati, dan bukan test untuk data. Akan tetapi, apabila data yang diamati adalah stationer, hal ini akan meningkatkan akurasi dari analisis VAR.

(4) Penentuan Lag Optimal Model VAR. Untuk dapat melakukan estimasi model VAR maka perlu ditentukan seberapa banyak variabel lag lenght dibutuhkan dalam model. Di dalam model autoregresi dimana peran waktu sangat berpengaruh maka peranan lag didalam model menjadi sangat penting. Penentuan lag lenght juga bertujuan untuk mendapatkan model yang tepat untuk diestimasi, dimana model tersebut ditentukan oleh banyaknya jumlah lag yang digunakan.

Tabel 1. Penentuan Lag Optimal

\begin{tabular}{lc}
\hline \multicolumn{1}{c}{ Kriteria } & \multicolumn{1}{c}{ Rumus } \\
\hline $\begin{array}{l}\text { Final Prediction Error } \\
(F P E)\end{array}$ & {$\left[\frac{R S S}{T}\right] X \frac{T+k}{T-k}$} \\
$\begin{array}{l}\text { Akaike Information } \\
\text { Criterion (AIC) }\end{array}$ & {$\left[\frac{R S S}{T}\right] X e^{(2 k / T)}$} \\
$\begin{array}{l}\text { Schwarz Information } \\
\text { Criterion (SIC) }\end{array}$ & {$\left[\frac{R S S}{T}\right] X T^{k j / T}$} \\
\hline
\end{tabular}

Penentuan jumlah lag dalam model VAR ditentukan pada kriteria informasi yang direkomendasikan oleh Final Prediction Error (FPE), Akaike Information Criterion (AIC), Schwarz Criterion (SC), dan Hannan-Quinn (HQ). Tanda bintang pada lag optimal menunjukkan lag optimal yang direkomendasikan oleh kriteria diatas. Beberapa rumus yang biasa dipakai untuk menentukan lag optimal.

(5) Innovation Accounting. Pada dasarnya test ini digunakan untuk menguji struktur dinamis dari sistem variabel dalam model yang diamati, yang dicerminkan oleh variabel inovasi (innovation variable). Dengan kata lain, test ini merupakan test terhadap variabel inovasi (innovation variable). Tes ini terdiri dari the impulse response dan the cholesky decomposition. The Impulse Responses digunakan untuk melihat efek gejolak (shock) suatu standar deviasi dari variabel invovasi terhadap nilai sekarang (current time values) dan nilai yang akan datang (future values) dari variabel-variabel endogen yang terdapat dalam model yang diamati.

The Cholesky Decomposition atau biasa disebut juga dengan The Variance Decomposition memberikan informasi mengenai variabel inovasi yang relatif lebih penting dalam VAR. Pada dasarnya test ini merupakan metode lain untuk menggambarkan sistem dinamis yang terdapat dalam VAR. Tes ini digunakan untuk menyusun perkiraan error variance suatu variabel, yaitu seberapa besar perbedaan antara variance sebelum dan sesudah shock, baik shock yang berasal dari diri sendiri maupun shock dari variabel lain.

\section{HASIL DAN PEMBAHASAN}

\section{Pengujian Uji Akar Unit}

Pengujian ini menggunakan program Eviews versi 7 , dan menggunakan Augmented DickeyFuller Test untuk melakukan uji akar unit (Unit Root Test) untuk menguji apakah variabel suku bunga sebagai proxy instrumen kebijakan moneter, pengeluaran pemerintah sebagai proxy kebijakan fiskal, tingkat inflasi dan pendapatan nasional bersifat stationer atau tidak.

Hasil uji unit akar untuk variabel Y menunjukkan nilai absolut statistik ADF (18.43398) lebih besar daripada nilai kritis MacKinnon pada level kepercayaan sebesar $1 \%(-3,615588)$ sehingga dapat dikatakan bahwa shock perubahan pendapatan nasional sudah stasioner (lihat Tabel 2).

Pengujian untuk variabel kebijakan fiskal (G) menunjukkan bahwa variabel $G$ memiliki nilai absolut statistik ADF $(-4,586507)$ lebih besar daripada nilai kritis MacKinnon pada level kepercayaan sebesar 1 persen $(-3,615588)$ se- 
hingga dapat dikatakan bahwa data perubahan kebijakan fiskal sudah stasioner pada tingkat level.

Tabel 2. Hasil Uji Akar Unit

\begin{tabular}{cccc}
\hline Variabel & \multicolumn{3}{c}{ Hasil Pengujian } \\
& Akar Unit & Level & $\begin{array}{c}\text { Level } \\
\text { kepercayaan }\end{array}$ \\
\hline $\mathrm{Y}$ & 18,43398 & $1 \%$ & $-3,615588$ \\
& & $5 \%$ & $-2,941145$ \\
$\mathrm{G}$ & \multirow{2}{*}{$-4,586507$} & $10 \%$ & $-2,609066$ \\
& & $1 \%$ & $-3,615588$ \\
$\mathrm{r}$ & & $5 \%$ & $-2,941145$ \\
& $-3,709253$ & $10 \%$ & $-2,609066$ \\
\multirow{2}{*}{ Inf } & & $1 \%$ & $-3,615588$ \\
& 4,586507 & $10 \%$ & $-2,941145$ \\
& & $1 \%$ & $-2,609066$ \\
& & $5 \%$ & $-2,615588$ \\
& & $10 \%$ & $-2,609066$ \\
\hline
\end{tabular}

Sumber: Perhitungan EViews

Hasil uji akar unit untuk variabel kebijakan moneter (r) menunjukkan bahwa variabel $r$ memiliki nilai absolut statistik ADF $(-3,709253)$ lebih besar daripada nilai kritis MacKinnon pada level kepercayaan sebesar 1\% $(-3,615588)$ sehingga dapat dikatakan bahwa data perubahan kebijakan moneter sudah stasioner pada tingkat level. Sementara itu hasil uji akar unit untuk variabel inflasi menyatakan bahwa variabel inflasi memiliki nilai absolut statistik ADF $(4,586507)$ lebih besar daripada nilai kritis MacKinnon pada level kepercayaan sebesar 1\% $(-3,615588)$ sehingga dapat dikatakan bahwa data perubahan inflasi sudah stasioner pada tingkat level. Dari hasil tersebut maka dapat disimpulkan bahwa seluruh variabel sudah lolos uji akar unit sehingga bisa dilakukan estimasi.

\section{Pengujian Kelambanan VAR}

Dalam membentuk model VAR, maka lebih lebih awal harus ditentukan dulu berapa jumlah lag yang paling sesuai dengan model. Untuk menentukan jumlah lag yang paling sesuai dengan model, maka kriteria yang di gunakan adalah di dasarkan pada nilai uji Akaike Information Criterion (AIC) dan Schwarz Information Criterion (SIC) yang menghasilkan nilai minimum. Hasil uji kelambanan VAR dapat dilihat pada Tabel 3 .

Hasil analisis menunjukkan bahwa nilai AIC dan SIC pada lag 2 menurun dan meningkat lagi pada lag 3. Dengan demikian jumlah lag yang paling sesuai dengan model adalah lag 2, dengan nilai AIC sebesar 56,39185 dan nilai SIC sebesar 57,97537. Hasil uji kelambanan adalah bahwa derajat kelambanan variabel-variabel tersebut untuk menjadi stasioner adalah pada $\operatorname{lag} 2$.

\section{Hubungan Variabel Dependen dan Independen}

Hasil pengujian untuk melihat hubungan variabel dependen dengan variabel independen dapat dilihat pada Tabel 4. Hubungan parsial dengan uji-t untuk Indonesia diketahui memiliki lima hubungan antar variabel yang lolos uji-t. Dipandang dari sudut kecepatan variabel yang mempengaruhi variabel dependen sendiri maka semua hanya variabel pendapatan nasional yang konsisten mempengaruhi variabel sendiri pada lag 1 dan 2, sedangkan variabel kebijakan fiskal, kebijakan moneter dan inflasi mempengaruhi variariabel sendiri pada lag pertama.

Dipandang dari sudut kecepatan mempengaruhi variabel antara variabel kelambanan terhadap variabel lain maka hanya variabel pendapatan nasional, kebijakan fiskal dan inflasi yang mempengaruhi variabel yang lain. Pendapatan nasional mempengaruhi variabel kebijakan fiskal pada lag 1 dan 2, demikian juga

Table 3. Hasil Uji Kelambanan VAR

\begin{tabular}{ccccccc}
\hline Lag & LogL & LR & FPE & AIC & SC & HQ \\
\hline 0 & $-1181,873$ & NA & $4,81 \mathrm{e}+23$ & 65,88184 & 66,05779 & 65,94325 \\
1 & $-1036,500$ & 250,3658 & $3,66 \mathrm{e}+20$ & 58,69442 & 59,57415 & 59,00147 \\
2 & $-979,0533$ & $86,16925^{*}$ & $3,80 \mathrm{e}+19^{*}$ & $56,39185^{*}$ & $57,97537^{*}$ & $56,94454^{*}$ \\
3 & $-970,2441$ & 11,25629 & $6,22 \mathrm{e}+19$ & 56,79134 & 59,07864 & 57,58967 \\
\hline
\end{tabular}

* indicates lag order selected by the criterion

LR: sequential modified LR test statistic (each test at 5\% level), FPE: Final prediction error, AIC: Akaike information criterion, SC: Schwarz information criterion, HQ: Hannan-Quinn information criterion 
variabel kebijakan fiskal mempengaruhi pendapatan nasional pada lag 2. Dengan demikian terdapat hubungan kausalitas dua arah antara pendapatan nasional, dan kebijakan fiskal.

Tabel 4. Hubungan Variabel Dependen dan Independen

\begin{tabular}{cll}
\hline \multicolumn{4}{c}{ Kecepatan Mempengaruhi } \\
\hline $\begin{array}{c}\text { Dengan Lag Variabel } \\
\text { Sendiri }\end{array}$ & $\begin{array}{c}\text { Dengan Lag Variabel } \\
\text { Lain }\end{array}$ \\
\hline 1. $\mathrm{Y}(-1) \rightarrow \mathrm{Y}$ & 1. $\mathrm{Y}(-1) \rightarrow \mathrm{G}$ \\
2. $\mathrm{Y}(-2) \rightarrow \mathrm{Y}$ & 2. $\mathrm{Y}(-2) \rightarrow \mathrm{G}$ \\
3. $\mathrm{G}(-2) \rightarrow \mathrm{G}$ & 3. & $\mathrm{G}(-2) \rightarrow \mathrm{Y}$ \\
4. $\mathrm{INF}(-1) \rightarrow \mathrm{R}$ & 4. & $\mathrm{INF}(-1) \rightarrow \mathrm{Y}$ \\
5. $\mathrm{R}(-1) \rightarrow \mathrm{R}$ & & \\
\hline
\end{tabular}

\section{Pengujian Impulse Response}

Gambar 1 menunjukkan bahwa perubahan suku bunga mula-mula direspon positif sampai tahun ketiga dan selanjutnya direspon negatif sampai tahun ke 6 dan menghilang menuju titik keseimbangan. Sementara itu perubahan pengeluaran pemerintah direspon negatif oleh inflasi.

Kondisi ini mengindikasikan bahwa kebi- jakan moneter yang ketat dan kebijakan fiskal yang ekspansif akan dapat menurunkan inflasi walaupun dalam tempo yang pendek. Peningkatan suku bunga terhadap inflasi memiliki pengaruh tidak langsung dan hanya direspon secara temporer. Indikasinya, kebijakan fiskal yang ekspansif akan meningkatkan inflasi namun selanjutnya akan kembali ke titik keseimbangan.

Respon output terhadap perubahan suku bunga dan kebijakan fiskal adalah positif, artinya penerapan kebijakan moneter yang ketat dalam jangka pendek akan meningkatkan pertumbuhan ekonomi. Kestabilan penerapan kebijakan moneter akan dapat mendorong sektor riil.

Gambar 2 menunjukkan respon kebijakan fiskal dan moneter terhadap perubahan inflasi dan output. Tingkat suku bunga mula-mula memberikan respon positif sampa tahun pertama, namun selanjutnya memberikan respon negatif sampai tahun keempat dan selanjutnya menuju titik kesimbangan. Kenaikan inflasi akan direspon oleh penurunan suku bunga. Hal ini menunjukkan bahwa kebijakan tingkat suku bunga harus dilakukan secara hati-hati untuk

Response to Cholesky One S.D. Innovations \pm 2 S.E.
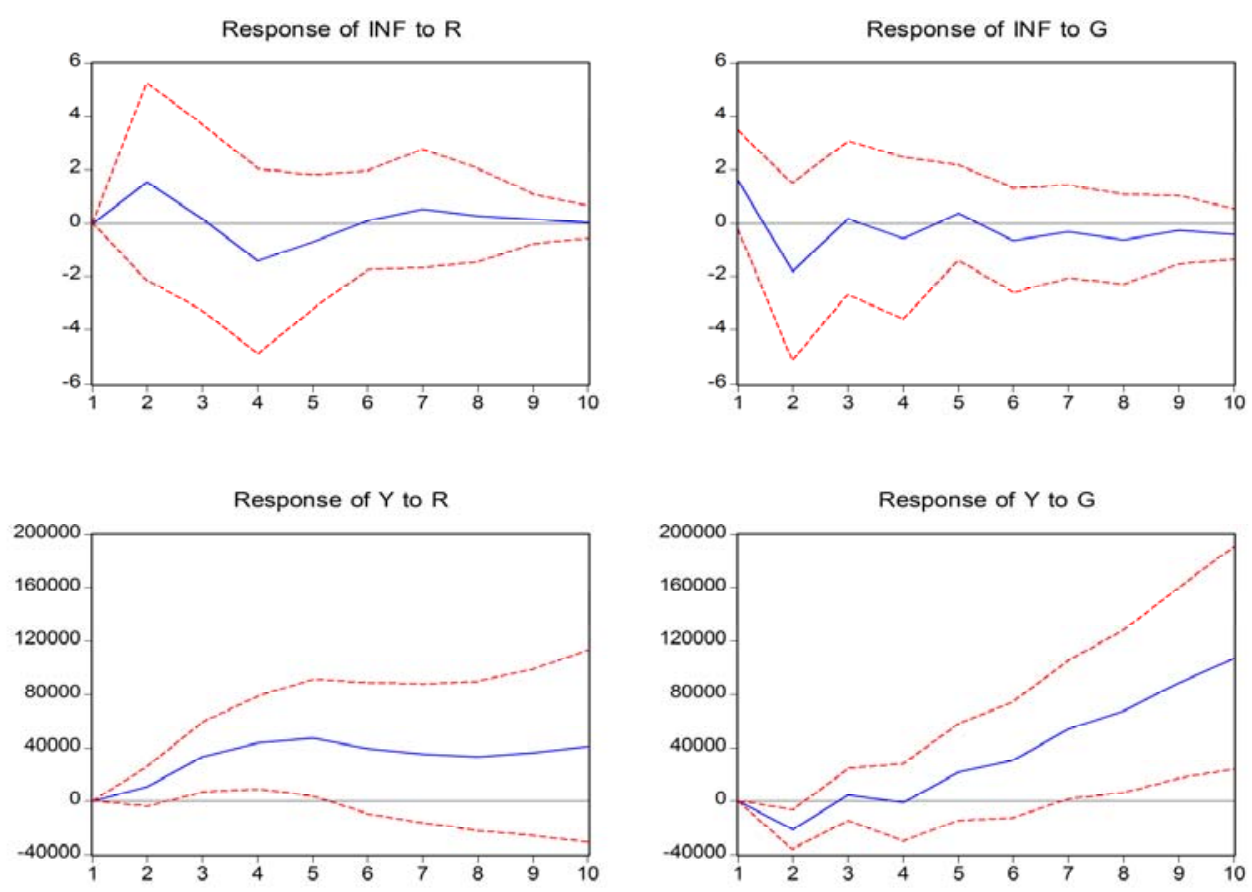

Gambar 1. Respon Inflasi dan Output terhadap Variabel Kebijakan 
Response to Cholesky One S.D. Innovations \pm 2 S.E.
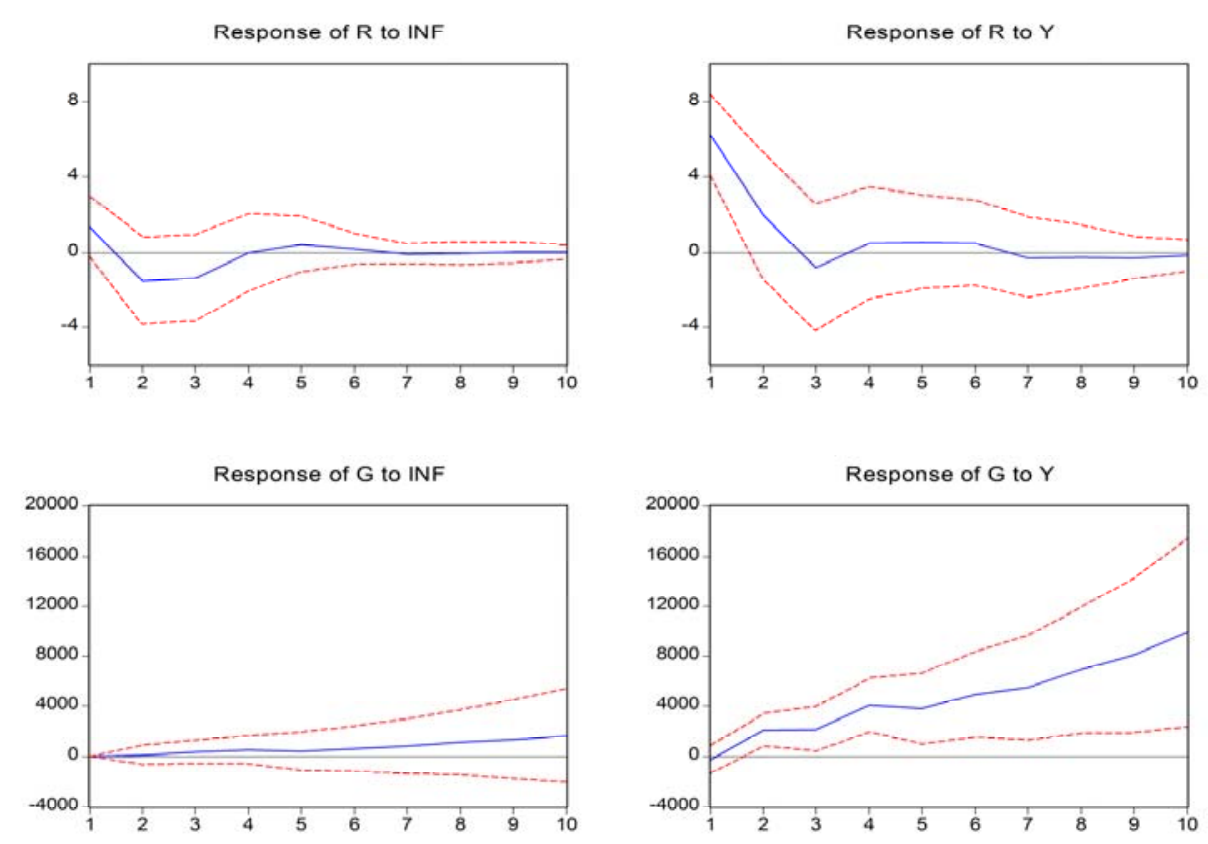

Gambar 2. Respon Kebijakan Fiskal dan Moneter Terhadap Inflasi dan Output

menjaga iklim yang kondusif bagi sektor riil.

Inovasi perkembangan output dan inflasi secara keseluruhan direspon positif oleh kebijakan fiskal. Sementara itu kebijakan fiskal direspon positif oleh o utput. Hal ini berarti penerapan kebijakan fiskal yang efektif akan meningkatkan pendapatan nasional.

\section{Hasil Pengujian Variance Decomposition}

Variance decomposition memisahkan variasi perubahan shock dari setiap variabel terhadap variabel lain dalam mod el. Setiap variabel perubahan dalam model diasumsikan tidak berkorelasi. Variance decomposition menggambarkan besarnya sumbanga $\mathrm{n}$ pengaruh dari suatu variabel perubahan terhadap variabel lain dalam model.

Hasil analisis menyata kan bahwa variance decomposition dari variabel pendapatan nasional menjelaskan bahwa pada periode ke 1 dipengaruhi oleh variabel itu sendiri yaitu 100 persen. Namun pada periode ke 2 nilainya terus menu-

Tabel 5. Hasil Pengujian Variance Decomposition

\begin{tabular}{cccccc}
\hline Period & S.E. & Y & G & INF & R \\
\hline 1 & 42882,06 & 100,0000 & 0,000000 & 0,000000 & 0,000000 \\
2 & 72865,90 & 87,46743 & 8,683754 & 1,603833 & 2,244986 \\
3 & 102376,0 & 83,00555 & 4,621864 & 0,882186 & 11,49040 \\
4 & 137398,6 & 80,50905 & 2,573073 & 0,491439 & 16,42644 \\
5 & 163580,6 & 76,11405 & 3,553449 & 0,347007 & 19,98550 \\
6 & 186948,9 & 74,53205 & 5,427083 & 0,310497 & 19,73037 \\
7 & 212388,6 & 70,96581 & 10,58545 & 0,409363 & 18,03938 \\
8 & 242788,3 & 67,85728 & 15,82927 & 0,622511 & 15,69094 \\
9 & 280405,3 & 63,87606 & 21,84141 & 0,821852 & 13,46067 \\
10 & 326637,2 & 60,61647 & 26,90172 & 0,986343 & 11,49547 \\
\hline
\end{tabular}

Cholesky Ordering: Y G INF R 
run sampai 87,46 persen dan menurun kembali sampai periode 10. Kontribusi shock variabel kebijakan fiskal terhadap pendapatan nasional mula-mula hanya sebesar 8,68 persen pada periode ke 2 dan terus mengalami penurunan sampai periode ke-6, namun selanjutnya mengalami peningkatan sampai periode ke 10 hingga menjadi 26,90 persen.

Kontribusi shock variabel kebijakan moneter terhadap pendapatan nasional mula-mula hanya sebesar 2,24 persen pada periode ke 2 dan terus mengalami peningkatan sampai periode ke-5, namun selanjutnya mengalami penurunan sampai periode ke 10 menjadi 11,49 persen. Sementara hasil pengujian variance decomposition untuk variabel inflasi menyatakan bahwa kontribusi shock variabel inflasi terhadap pendapatan nasional pada awalnya sekitar 1,60 persen pada periode ke 2 namun pergerakannya sangat fluktuasi dan menurun sampai periode ke 6 hingga tinggal 0,31 persen. Pergerakan shock variabel selanjutnya adalah kembali meningkat sampai periode ke 10 hingga mencapai 0,98 persen.

\section{SIMPULAN}

Hasil penelitian menyimpulkan bahwa kebijakan moneter yang ketat dan kebijakan fiskal yang ekspansif akan dapat menurunkan inflasi walaupun dalam tempo yang pendek. Peningkatan suku bunga terhadap inflasi memiliki pengaruh tidak langsung dan hanya direspon secara temporer. Ind ikasinya, kebijakan fiskal yang ekspansif akan meningkatkan inflasi namun selanjutnya akan kembali ke titik keseimbangan.

Respon output terhadap perubahan suku bunga dan kebijakan fiskal adalah positif, artinya penerapan kebijakan moneter yang ketat dalam jangka pendek akan meningkatkan pertumbuhan ekonomi. Kestabilan penerapan kebijakan moneter akan dapat mendorong sektor riil.

Tingkat suku bunga mula-mula memberikan respon positif sampa tahun pertama, namun selanjutnya memberikan respon negatif sampai tahun keempat dan selanjutnya menuju titik kesimbangan. Kenaikan inflasi akan dires- pon oleh penurunan suku bunga. Hal ini menunjukkan bahwa kebijakan tingkat suku bunga harus dilakukan secara hati-hati untuk menjaga iklim yang kondusif bagi sektor riil.

Inovasi perkembangan otput dan inflasi secara keseluruhan direspon positif oleh kebijakan fiskal. Sementara itu kebijakan fiskal direspon positif oleh pendapatan nasional. Hal ini berarti penerapan kebijakan fiskal yang efektif akan meningkatkan pendapatan nasional.

Rekomendasi Kebijakan. Rekomendasi yang bisa diberikan untuk penelitian ini adalah sebagai berikut: (1) Otoritas moneter dalam menetapkan kebijakan tingkat suku bunga hendaknya dilakukan secara hati-hati karena akan memiliki dampak terhadap sektor riil dan pertumbuhan ekonomi. (2) Kebijakan fiskal tidak hanya berorientasi pada target pertumbuhan ekonomi namun hendaknya juga memperhatikan stabilisasi harga karena pengaruhnya yang cukup besar terhadap inflasi (3) Pentingnya koordinasi yang lebih sinergis, untuk mencapai keselarasan pencapaian kemakmuran masyarakat.

\section{DAFTAR PUSTAKA}

Bank Indonesia. 2003. Bank Indonesia: Bank Sentral Republik Indonesia, Tinjauan Kelembagaan, Kebijakan, dan Organisasi, Pusat Pendidikan dan Studi Kebanksentralan Bank Indonesia. 2005-2006. Laporan Perekonomian Indonesia

Bank Indonesia. 2007. Statistik Ekonomi dan Keuangan Indonesia. Bank Indonesia

Claeys, Peter. 2005. Monetary and Budgetary Policy Interaction: An SVAR Analysis of Stabilization Policies. European University Institute.

Djojosubroto, Dono Iskandar. 2004. Koordinasi Kebijakan Fiskal dan Moneter di Indonesia dalam Subiyantoro, Heru dan Singgih Riphat (Ed). Kebijakan Fiskal, Pemikiran, Konsep dan Implementasi. Jakarta. Penerbit Buku Kompas 
Gujarati, D. 2005. Basic Econometric. New York: McGraw-Hill, Inc.

Indrawati, Y. 2007. Interaksi Kebijakan Fiskal dan Moneter di Indonesia: Pendekatan Vector Autoregression. Makalah Seminar Monetary \& Macroeconomy Policy. Universitas Indonesia.

Leith, Campbell and Simon Wren-Lewis. 2000. Interaction between Monetary and Fiscal Policy Rule. The Economic Journal, 110, March

Mishkin, Frederic S. 1995. The Economics of Money, Banking and Financial Markets, Fourth Edition. New York: Harper Collins College Publishers.
Nizar, M.A. 2010. Arah Kebijakan Fiskal dan Moneter di Indonesia. Skripsi. Universitas Indonesia. Tidak dipublikasikan.

Samuelson, Paul dan William D. Nordhaus. 1985. Economics. 12 th Edition. Mc GrawHill

Suparmoko. 2000. Keuangan Negara dalam Teori dan Praktek, Edisi 5. Yogyakarta: BPFE.

Usman, Marzuki. 2004. Reformasi Sektor Fiskal dan Finansiil Indonesia dalam dekade 1970-an dan 1980-an. dalam Subiyantoro, Heru dan Singgih Riphat (Ed). 2004. Kebijakan Fiskal, Pemikiran, Konsep dan Implementasi. Jakarta: Penerbit Buku Kompas. 